ensuing year. Publishers $J 1$ would forward the passbook to $J 2$ who would make their allocation in the knowledge of what $J 1$ had done; similarly for $J 3$, who would then return the book to $S$. This operation would be repeated each year, or whatever would be found the most useful interval. Any young scientist, or scientist from abroad, or scientist entering a new field, being duly accredited, could be given a standard starting allocation of say five pages in any journal of his choice. In the course of 2 or 3 years he could then work himself into the situation of $S$.

The printing would be done according to a system now coming into use for some reports of symposia, and so on. The journals would supply the author with paper of standard form on which his work would have to be typed according to standard instructions. Each sheet would be photographically reproduced as a page of the journal, exactly as the author submits it. The author would then know automatically how he is using up his page allocation. If a paper is submitted by several authors, they would have to agree among themselves as to how many pages each would contribute from his own allocation, and inform the publishers accordingly.

The advantages to the scientific community generally would include the end of refereeing and editing other people's work, no correcting of printer's proofs, speedier publication and speedier production of offprints, an end to the production of preprints, and a reduction of costs all round. There would be other advantages to the publishers, such as more reliable estimation of the amount of material to be published within any given time.

If an author maintained a high standard, he would earn all the allocation he needs. If an author published bad or badly presented work, he would find his allocation greatly reduced. The discipline on authors would be wonderfully salutary!
The interesting problem would be the business of allocating pages. The publishers of a journal could prescribe a total number of pages for a year. Then they could ask a small panel drawn from the authors who had published most in that journal during a few previous years to allocate this total among the authors applying. The deliberations of the panel might be entertaining--more entertaining than refereeing papers.

Other people can doubtless suggest many improvements to the scheme, but in one form or another it might solve some of the many problems now besetting those who have the responsibility for seeing that scientific research is published as efficiently as possible.

Yours faithfully, W. H. MCCREA

Astronomy Centre,

University of Sussex

\section{Short RNA Chains}

SIR,-It would be interesting to know whether the discovery mentioned by your Cell Biology Correspondent ${ }^{1}$ that "short RNA chains can in vitro and may in vivo act as primers for the self replication of double and single stranded DNAs by DNA polymerases which elongate DNA chains in the $5^{\prime}-3^{\prime}$ direction, polymerizing deoxy nucleotide triphosphates onto $3^{\prime}$ hydroxy groups of primers" is related to the finding made some years ago that small amounts of RNAase-resistant RNA seemed to be associated with DNA after the nucleic acids from HeLa cells ${ }^{2}$ or mouse ascites sarcoma cells ${ }^{3}$ had been separated by chromatography or density gradient centrifugation.

$$
\begin{aligned}
& \text { Yours faithfully, } \\
& \text { J. S. PEARSON } \\
& \text { P. T. SPEAKMAN }
\end{aligned}
$$

Department of Textile Industries,

The University,

Leeds LS2 9JT
${ }^{1}$ Nature, 238, 247 (1972).

${ }^{2}$ Levis, A. G., Krsmanovic, V., and Errera, M., Biochim. Biophys. Acta, 145, 577 (1967).

${ }^{3}$ Watson, J. D., and Ralph, R. K., Biochim. Biophys. Acta, 138, 89 (1967).

\section{Erratum}

IN the article "New Antifertility Agent -an Orally Active Prostaglandin-ICI 74,205" by Anant P. Labhsetwar (Nature, $238,400 ; 1972)$, the double bone in the upper side chain in ICI 74205 should have been shown in the cis and not the trans position in the structural formula on p. 401.

\section{International Meetings}

October 4, Application of Finite Elements in Mechanical Engineering Design--A Survey of Current Practice, London (Institution of Mechanical Engineers, 1 Birdcage Walk, London SW1H 9JJ).

October 12, Recent Developments in Compact High Duty Heat Exchangers, London (Institution of Mechanical Engineers, 1 Birdcage Walk, London SW1H 9JJ).

October 16-20, National Society for Clean Air Conference, Scarborough (National Society for Clean Air, 134-137 North Street, Brighton BN1 1RG).

October 24-26, Site Testing of Pumps, London (Institution of Mechanical Engineers, 1 Birdcage Walk, London SW1H 9JJ).

October 24-26, The Car of the FutureThe Practical Influence of Legislative and Economic Factors - Reliability - Easier Maintenance, London (Institution of Mechanical Engineers, 1 Birdcage Walk, London SW1H 9JJ).

October 26, A Study of the Fixation of Fractures using Plates: Clinical Complications of the Use of Such Devices and an Experimental Study of their Characteristics, London (Institution of Mechanical Engineers, 1 Birdcage Walk, London SW1H 9JJ).

\section{HOW TO BUY NATURE}

Volumes start in January, March, May, July, September and November, but subscriptions may begin at any time. The direct postal price per subscription is : 12 MONTHS * (52 issues per title)

$\begin{array}{lcc} & \begin{array}{c}\text { Surface mail } \\ \text { UK and } \\ \text { worldwide } \\ £ 14\end{array} & \begin{array}{c}\text { U.S.A. and } \\ \text { Canada }\end{array} \\ \begin{array}{l}\text { Nature (Friday) } \\ \text { Nature + } \\ \text { Nature Physical Science }\end{array} & £ 24 & \$ 83 \\ \begin{array}{l}\text { Nature + } \\ \text { Nature New Biology }\end{array} & £ 24 & \$ 83 \\ \text { All three editions } & £ 29.50 & \$ 108 \\ \text { Annual Index } & £ 1 & \$ 3\end{array}$

* Rates for shorter periods pro rata (minimum three months) (Charge for delivery by air mail on application)
Editorial and Publishing Offices of NATURE

MACMILLAN JOURNALS LIMITED 4 LITTLE ESSEX STREET, LONDON WC2R 3LF Telephone Number: 01-836 6633. Telegrams: Phusis London WC2R 3LF Telex 262024

711 NATIONAL PRESS BUILDING WASHINGTON DC 20004 Telephone Number : 202-737 2355. Telex 64280 Subscription Department MACMILLAN JOURNALS LIMITED BRUNEL ROAD, BASINGSTOKE, HANTS

Telephone Number : Basingstoke 29242 American display advertisements NATURE SCIENTIFIC PUBLICATIONS INC 711 NATIONAL PRESS BUILDING WASHINGTON DC 20004 All other advertisements T. G. SCOTT \& SON, LIMITED

1 CLEMENT'S INN, LONDON WC2A 2ED Telephone : 01-242 6264/01-405 4743 Telegrams : Textualist London WC2A 2ED Registered as a newspaper at the Post Office Copyright (C) Macmillan Journals Limited, September 221972 